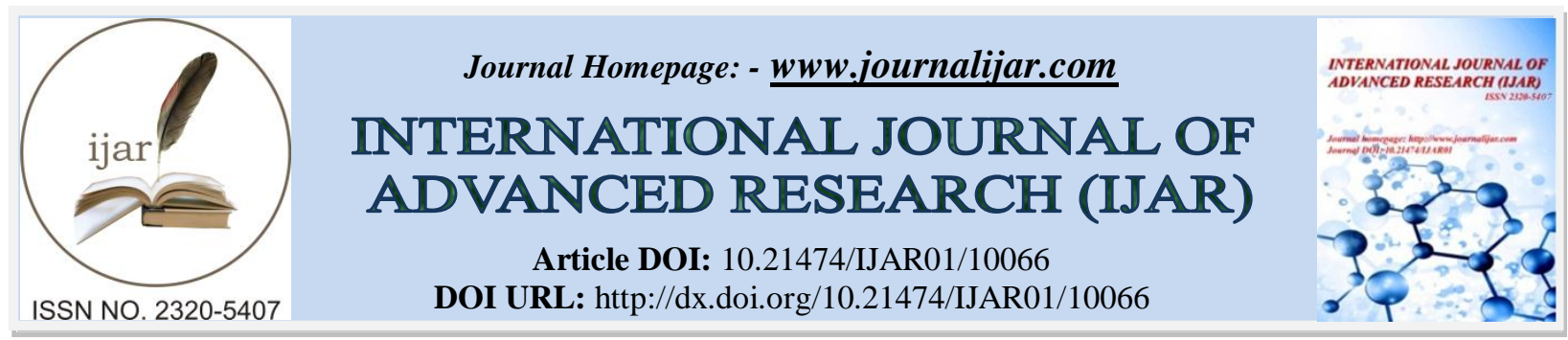

RESEARCH ARTICLE

\title{
PREVENTION OF HUMAN TRAFFICKING IN TIMOR TENGAH UTARA REGENCY(STUDY IN TAPEN BIKOMI FOUNDATION).
}

\section{Mariano Sengkoen ${ }^{1}$, Endah Setyowati $^{2}$ and Wike ${ }^{3}$.}

1. Postgraduate Student of National Security Studies, Brawijaya University.

2. Postgraduate Lecturer, Faculty of Administrative Science, Brawijaya University.

3. Postgraduate Lecturer, Masters Program of Women Studies, Brawijaya University.

\section{Manuscript Info}

\section{Manuscript History}

Received: 12 September 2019

Final Accepted: 14 October 2019

Published: November 2019

Key words:-

Tapen Bikomi Foundation, Prevention,

Human Trafficking

\begin{abstract}
The study aimed at describing and analyzing efforts to prevent human trafficking by the Tapen Bikomi Foundation in Timor Tengah Utara Regency. The Tapen Bikomi Foundation is one of the local NGOs and partners of the regional government of Timor Tengah Utara Regency in various human trafficking prevention activities in the area. Timor Tengah Utara Regency is one district in the province of East Nusa Tenggara, Indonesia. In Timor Tengah Utara Regency, human trafficking is one of the serious problems that has claimed many victims. Trends in human trafficking cases in Timor Tengah Utara Regency occur through illegal recruitment and sending a mode of migrant workers. This study was about the various efforts of the Tapen Bikomi Foundation in preventing the practice of human trafficking in Timor Tengah Utara Regency. Prevention efforts included things done for the community, for the government and together with the government in Timor Tengah Utara Regency. This research used a qualitative descriptive approach. Data obtained through in-depth interviews with informants, observations not involved in the activities of the Tapen Bikomi Foundation and documentation studies. The results showed that in preventing human trafficking in the Timor Tengah Utara Regency, the Tapen Bikomi Foundation carried out three main activities that is, empowering the community, building a network of cooperation with the government and strengthening the capacity and policies of government institutions.
\end{abstract}

Copy Right, IJAR, 2019,. All rights reserved.

\section{Introduction:-}

Human trafficking is a serious threat to human life, society, and nation (Soepadmo, 2003: 10). The development of cases and the magnitude of the potential and impact of human trafficking has spawned anxiety, ranging from local to the international level (Widiastuti, 2010). Indonesia is not immune to threats and attacks from the human trafficking crime network, whether as the area of origin of victims, transit areas and destination areas (Suparmin, 2013). This condition is the reason the problem of human trafficking is considered as one threat to the state.

According to the International Organization for Migration (IOM) report, the number of human trafficking victims from Indonesia between 2005-2017 reached 8876 people (www.indonesia.iom.int, accessed on 12 April 2018). In 
Indonesian, the regions with the largest number of human trafficking cases are in the five provinces that included in the red zone category of human trafficking cases, namely East Nusa Tenggara (in Indonesian called Nusa Tenggara Timur, abbreviated as NTT), West Nusa Tenggara, Central Java, East Java, and West Java.

Data from the National Departement of Indonesian Workers Assignation and Protection states that until 2017 there are about 2.7 to 3 million Indonesian workers in Malaysia. 50\% of this number do not have official or illegal documents. In this amount, NTT accounted for around 6000 illegal workers. NTT is also a provincial donor of the largest Indonesian labor mortality. Of the total 69 Indonesian workers who died in Malaysia in 2017, 62 of them came from NTT. In fact, until March 2018, there have been 19 deaths of migrant workers from NTT. All the victims were illegal workers who were allegedly victims of human trafficking practices.

According to the NTT Departement of Indonesian Workers Recruitment, Assignation, and Protection report, in the last five years of data, the death of migrant workers from NTT continues to increase. In 2013, 31 people died (11 legal and 20 illegal workers), in 2014, 21 people (8 legal and 13 illegal workers), in 2015, 28 people (5 legal and 23 illegal workers), 201649 people (7 are legal and 42 are illegal workers) and in 2017 there are 63 people (8 are legal and 55 are illegal workers). Data from the NTT Regional Police, in 2013 there were 33 cases of human trafficking, 42 cases in 2014, 52 cases in 2015, 62 cases in 2016, 27 cases in 2017 and 11 cases as of March 2018.

Middle North Timor (in Indonesian called Timor Tengah Utara, abbreviated as TTU) is one district in the NTT Province. According to data from the Central Bareau of Statistic in TTU Regency, the population in 2017 numbered 253,587 people, with 125,908 men and 127,679 women. According to the same sources, for the period of January April 2016, the number of legal workers from this district was 51 people. Data from the Department of Manpower and Population of TTU Regency shows that up to February 2019 there were 4021 migrant workers from TTU Regency working illegally or non-procedurally at home and abroad the country. This data illustrates the large potential for the occurrence of human trafficking practices with an illegal labor mode in the TTU Regency.

This data showed that the practice of human trafficking through the illegal labor mode is very alarming. Therefore, efforts to prevent the practice of human trafficking needed. The United Nations (UN) Convention on Transnational Crime states that efforts to tackle human trafficking must sponsor by the governments of each country, including socio-economic development, involving cooperation with the private sector and the whole community, sustainable and accountable, based on knowledge, and by adopting a diverse approach (Barrett \& Shaw, 2011).

The legal basis for efforts to combat human trafficking in Indonesia has been established through Undang-undang Number 21 of 2007 concerning the Prevention of Criminal Acts of Trafficking in Persons (written UU No.21 of 2007). The law mentioned the importance of the movement of all elements of the nation to jointly strive and act to eradicate the practice of human trafficking. Article 58 of Law No. 21 of 2007 emphasized that in overcoming the problem of human trafficking, the government needs to involve various institutions outside the government elements, including various Non-Governmental Organizations (abbreviated as NGOs) that pay attention to human trafficking, both on a local, regional, national scale and international.

NGOs are voluntary institutions outside government institutions that are nonprofit and move because of concern to change lives in a particular environment for the better. Peter Hagul mentioned the four roles of NGOs in the framework of working towards the interests of the community. First, as a facilitator and catalyst, facilitating and taking part in determining alternative solutions to community problems. Second, as trainers and educators, which help provide information and build community capacity. Third, capital accumulation by bridging the community with relevant sources of funds. Fourth, undertaking simultaneous projects in empowerment to increase community independence (Hagul, 1992). All of this leads to the formation of public awareness, independence and community participation and government support for community empowerment in confronting and resolving various community problems, including human trafficking issues.

In a study entitled "What in the World Are Anti-Trafficking NGOs Doing? Findings from a Global Study"(2016) Limoncelli identified various efforts made by NGOs in the world in anti-trafficking activities. The research conducted on 1,861 NGOs and mentions several types of activities carried out by NGOs, education and public awareness, advocacy for the legislative body and policy, legal services, counseling, shelter, formal education help, education and health services, work and skills training, training on legal application and help to victims trafficking. 
Research conducted by Arif with the title "The Role of the International Organization for Migration (abbreviated as IOM) in Overcoming Human Trafficking in Indonesia in 2010-2014" (2016) illustrates the form of efforts and the role of the International Organization for Migration (IOM) in overcoming the problem of trafficking in Indonesia in the years 2010-2014. From this research, appear several steps undertaken by IOM in expecting and dealing with the problem of human trafficking in Indonesia as follows. First, to assist the Indonesian government in making legal instruments that govern human trafficking issues. Second, collaborating with the Indonesian government to overcome the problem of human trafficking in Indonesia. third, collaborating with the Indonesian National Police in monitoring human trafficking issues in Indonesia.

Practically, there are many conditions of individuals, communities, and institutions that provide opportunities for the practice of human trafficking. Therefore, efforts to prevent human trafficking require a comprehensive approach model, to improve these conditions. One model that used is the Spectrum Of Prevention models. The model planned by Cohen \& Swift comprises six levels with an ever-increasing range, ranging from individuals and families, norms in society, institutional practices and policies and legal products. The six levels of the spectrum of prevention are as follows. First, strengthen the knowledge and abilities of individuals. Second, promoting community education. Third education of community service providers or prevention providers. Fourth, expand the network and build coalitions. Fifth, change the practice of organizations or institutions involved in prevention efforts. Sixth, influencing policies and regulations (Cohen \& Swift, 1998). Even each level of the Spectrum of Prevention have different intervention, those levels have linkages one with another. Thus, to get larger transformative power in preventing, each level of Spectrum of Prevention combined and synergized on some pattern.

As a local NGO in partnership with the regional government of TTU Regency, Tapen Bikomi Foundation is undertaking various actions in preventing human trafficking. Since 2014, the Tapen Bikomi Foundation has also received support from various ministries and international NGOs to develop human trafficking prevention activities in TTU Regency. This study aims to identify, describe and explain the forms of prevention activities carried out by the Tapen Bikomi Foundation in TTU Regency, by reflecting on the spectrum of prevention above.

\section{Research Method:-}

The approach used in this research is a qualitative approach, with a case study method. Case studies were intended to look at programs, processes, events or activities on a particular problem. This research conducted from January to February 2019 in TTU Regency. The purposive sampling technique used in finding the research taking into account the place or target area for implementing human trafficking prevention efforts by the Tapen Bikomi Foundation. The focus of this research is about the activities carried out by the Tapen Bikomi Foundation in preventing human trafficking in TTU Regency.

Sources of data in this study comprised primary data and secondary data. Primary data is the information taken from the informants. Meanwhile, secondary data is information got from various relevant documents and literature. Data collection techniques in this study comprised in-depth interviews with informants, uninvolved observations and literature studies. Determination of informants in this study using purposive sampling techniques, taking into account the knowledge and involvement of informants in efforts to prevent human trafficking conducted by the Tapen Bikomi Foundation so that accurate information can be obtained. Informants in this study include the Chairperson of the Bikomi Tapen Foundation; Head of Letmafo Village, Insana Tengah District; Head of Atmen Village, West Insana District; Head of Manpower Placement and Development Division, Manpower and Transmigration Department of TTU Regency; Head of Family Empowerment, Social Department of TTU Regency; and Chief of Detective and Criminal, Timor Tengah Utara Police Department.

This study uses a source triangulation approach to conduct a credibility test of research findings. Meanwhile, the data analysis steps used are Interactive Data Analysis according to Miles and Huberman, which consists of data collections, data reduction, data display, and conclusion. The data analysis technique used in this study was a descriptive analysis in the form of an explanation of various forms of human trafficking prevention activities carried out by the Tapen Bikomi Foundation in Timor Tengah Utara Regency. 


\section{Results And Discussion:- Tapen Bikomi Foundation}

The Tapen Bikomi Foundation, was established on February 13, 2003, is a non-profit organization engaged in various fields of development, strengthening, empowerment and advocacy in social services to improve the standard of living of the community. The main working area of the Tapen Bikomi Foundation is in the TTU Regency, which includes 24 Districts and 193 Villages.

The vision carried out by the Tapen Bikomi Foundation is "Realizing Sustainable Improvement of the Poor's Living Standards". Tapen Bikomi Foundation as a partner of the regional government of TTU Regency carries out various activities within the service sector as the realization of the vision and mission of the institution. Four main service areas held, Economy, including Cooperatives and Small and Medium Enterprises (SMEs) activities; Healthy, including public health education such as HIV/AIDS and Nipza; Educate, including Skills Courses and Training (Computers, Automotive, Clothing and Catering), Community Reading Gardens and Education on Prevention of Trafficking in Persons; and Social Services, including social services such as services to elderly people outside the orphanage and services to homeless children outside the orphanage.

Since its inception, the Tapen Bikomi Foundation has paid attention to human trafficking as a serious problem in the local area. Human trafficking education and socialization carried out and integrated with HIV/AIDS education, both carried out within the school environment and community groups. It drives this because the spread and spread of HIV/AIDS are from migrant workers from TTU Regency, both those working at home and abroad.

On the way, in 2015 the Bikomi Tapen Foundation built cooperation with the Directorate of Literacy and Equality Education Development of the Directorate General of Early Childhood Education and Community Education, Ministry of Education and Culture of the Republic of Indonesia to conduct Education Activities for Preventing Trafficking in Persons. The activity aims to increase the capacity and capability of community institutions or organizations in preventing the practice of human trafficking. The Bikomi Tapen Foundation has carrying out human trafficking prevention training activities with participants comprising school principals, subject teachers, counseling and guidance teachers, tutors, community leaders and religious leaders in TTU Regency. Meanwhile, the Ministry of Education and Culture provided several budgets for implementing these activities. This collaboration then continued in the following years until 2018.

Since 2018, the Tapen Bikomi Foundation has also established partnerships with IOM. Through this collaboration, the Tapen Bikomi Foundation has to provide internal and external help and providing direct support to answer the needs of human trafficking victims from the TTU Regency. The main targets of help include support for returning the victim, medical and psychological rehabilitation, legal help in handling problems and social reintegration of victims. IOM provides financial support according to field needs. The financial support can also provide relevant or needed help in the fight against the practice of human trafficking, both in terms of prevention, protection of victims and legal proceedings for perpetrators, outside of the main target.

The support of resources and networks obtained from these collaborations has encouraged the Tapen Bikomi Foundation to conduct various human trafficking prevention activities in TTU Regency. The Tapen Bikomi Foundation has become more active in educating, campaigning, collaborating and advocating on human trafficking issues, through various other relevant approaches. One tangible form of this movement is the involvement and active role of the Tapen Bikomi Foundation in forming an anti-human trafficking task force at the level of TTU Regency in April 2018. The Tapen Bikomi Foundation itself was later included in the task force as one of the NGOs partner with local governments. The membership will further increase the chances of the Tapen Bikomi Foundation to work with various government and private elements to achieve the vision, mission, and goals of the institution and to ensure the safety of citizens in the local area. With this, the Tapen Bikomi Foundation further emphasized its existence in preventing human trafficking in the TTU Regency.

\section{Tapen Bikomi Foundation Activities In Preventing Human Trafficking}

In preventing human trafficking in TTU Regency, the Tapen Bikomi Foundation established a program in three major considerations. 


\section{Community Empowerment.}

The community empowerment approach applied in the form of education and training on preventing human trafficking to the community. Since 2015, this community empowerment effort has carried out in the form of educational activities to prevent human trafficking at the district level. This activity is a routine agenda of the Tapen Bikomi Foundation because of collaboration between the Tapen Bikomi Foundation and the Directorate of Literacy and Equality Education Directorate General of Early Childhood Education and Community Education, Ministry of Education and Culture of the Republic of Indonesia. The funding for this activity comes from the allocation of funds provided by the Ministry. Participants in the district-level human trafficking prevention education activities were delegates from schools, categorical groups, community leaders, traditional leaders, and religious leaders spread throughout the districts in Timor Tengah Utara Regency. This activity takes place once every year and carried out centrally in the capital city of Timor Tengah Utara Regency. In this activity, the Foundation also involved regional government delegation Manpower and Transmigration Department, Social Department, Women's Empowerment and Child Protection Agency, Youth and Sports Education Department, the Timor Tengah Utara Police Resort, representatives from the central ministry, Non-Government Organizations and academics to provide an understanding of human trafficking problems and prevention efforts according to the presenters' perspectives.

In addition, daily, Tapen Bikomi Foundation visits villages in Timor Tengah Utara Regency to conduct community empowerment activities. For community empowerment activities in the village, the foundation built cooperation and coordination with the local village government. Participants in these activities include village government officials, community leaders, traditional leaders, religious leaders, youth communities, and the community in the village. This activity usually takes place in the village office hall or other relevant places, according to the agreement between the Tapen Bikomi Foundation and the local village government. In this activity, the Foundation also involved local government officials from agencies related to human trafficking issues, to take part in providing relevant educational material to the community.

Every community empowerment activity carried out by Tapen Bikomi Foundation comprises two main parts, namely education, and training in preventing human trafficking. Through education, the Tapen Bikomi Foundation provides an understanding to the public about human trafficking. The material presented in educational activities to the public is about the understanding of human trafficking, the mode of modus used by perpetrators, and legal sanctions from the practice of human trafficking. The speaker delivers the material and ends with a question-andanswer session between the participant and the speaker. Meanwhile, in training activities, Tapen Bikomi Foundation explained the public about the mechanism of preventing human trafficking. The preventive mechanism presented about legal migration procedures. According to the informants, this caused by the trend of human trafficking cases that occurred in the Timor Tengah Utara Regency through the practice of illegal labor migration. Prevention skills training carried out through a simulation of the legal migration process carried out by the participants with the direction of the presenters or facilitators.

To address attention and participation of the larger public, Yayasan Tapen Bikomi also made public promotion about the prevention of human trafficking. Those promotions made by using some media, like a banner, poster, and sticker. Those media was published in some public space (government office, traditional market, bus station, etc), public transportation (bus and minibus), and some of those media given to the people. Yayasan Tapen Bikomi also uses social media like Facebook and Instagram. Besides, since 2015, Yayasan Tapen Bikomi also produced some short movies about some story about how human trafficking happened. These movies, until this research held, there were three movies made by Yayasan Tapen Bikomi. These movies accessed on YouTube. These movies are Sius, Impian dan Rupiah (https://www.youtube.com/watch?v=RZaNOOkz4N4); Haruskah Mati Demi Rupiah? (https://www.youtube.com/watch?v=-AWMPLsfeHk); Cukup Aku (https://www.youtube.com/watch?v=xWtPSFkthx0).

\section{Cooperation Networking.}

To ensure the continuation of efforts to prevent human trafficking in the TTU Regency, the Tapen Bikomi Foundation is building cooperation with the local government and several village governments in the district of TTU Regency. The cooperation in question is formal and ongoing cooperation to implement various forms of approaches in preventing human trafficking.

The collaboration between Tapen Bikomi Foundation and the regional government mainly takes place in the antihuman trafficking task force scheme at the TTU Regency level, as stipulated in the Regent's Decree of TTU No. 
190/KEP/HK/IV/2018 concerning the Establishment of an Anti-Trafficking and Prevention Task Force and Handling of Prospective Indonesian Workers/Troubled/Non-Procedural Indonesian Workers in TTU Regency. The task force comprises local government elements from the relevant agencies or offices, community social institutions, and district level district leaders. In the task force, there are four sub-groups, namely the Prevention, Trafficking and Illegal Workers Sub-Task Force; Sub-Task Force for Handling Social Health, Victim Rehabilitation and Repatriation; Sub-Task Force for Development and Law Enforcement; and the Collaboration and Organizational Sub-Task Force. The Bikomi Tapen Foundation is a member of the Sub-Task Force on Prevention, Training Trafficking and Illegal Workers. The task details of this sub-group are as follows. First, it collects information or public reports related to the direction or sign of sending prospective workers from the TTU Regency on a nonprocedural basis. Second, carry out operations or impromptu inspections to prevent the direction of prospective nonprocedural workers in public places such as land terminals, airports and seaports. Third, coordinate monitoring and determine prevention and treatment strategies according to community reports. Fourth evacuation of casualties. Fifth, collect data and provide guidance to victims and perpetrators under applicable regulations.

The Tapen Bikomi Foundation also builds direct cooperation with several regional government agencies in the TTU Regency, for various forms of activities related to human trafficking issues. Tapen Bikomi Foundation built coordination and provided support for performing agencies in various activities related to human trafficking issues. Specifically, the agencies referred to are as follows. First, the Department of Manpower and Transmigration, for the socialization of legal migration procedures. Second, the Office of Education, for educational activities to prevent human trafficking. Third, the Social Department, for the rehabilitation of victims of human trafficking.

Meanwhile, the Tapen Bikomi Foundation also established a network of cooperation with several village governments in the TTU Regency for several activities relevant to efforts to prevent human trafficking. There were already three villages that formally formed a partnership with the Tapen Bikomi Foundation. First, Letmafo village, in the Central Insana sub-district. Second, Atmen Village, in the West Insana sub-district. Third, Oenenu Village, in Central Bikomi sub-district. In this collaboration, the Tapen Bikomi Foundation help and support the village government to undertake various efforts to prevent human trafficking, including empowering community groups in the village, making village regulations for preventing human trafficking, and structuring a village environment safe from human trafficking practices through the help of media to promote migration legal and human trafficking prevention (in the form of posters, banners and stickers).

\section{Strengthening the Capacity and Policies of the Government.}

To support the effectiveness of the government in preventing human trafficking, Tapen Bikomi Foundation makes some approaches to strengthening the capacity and policies of the government in the TTU Regency. Besides, Tapen Bikomi Foundation also provides some relevant support and assistance. Practically, this role and effort in strengthening carried out through knowledge and skill sharing, policy advocacy and giving assistance support.

In the way of strengthening the capacity and practical skill of the governments by knowledge and skill sharing, Tapen Bikomi Foundation makes some discussions, dialogues and coordination. Through these activities the Tapen Bikomi Foundation contributes thoughts, insights, experiences, perspectives and skills which useful for various elements of government to determine an increasingly effective form of human trafficking prevention, by prioritizing community empowerment, creating a conducive climate of cooperation, decisive action to the perpetrators according to the applicable law and guarantee of protection for victims of human trafficking. The Tapen Bikomi Foundation also facilitates competent parties (including academics, experts and practitioners in the social, educational and legal fields) to deepen the insights and abilities of various elements of local government in preventing human trafficking.

Furthermore, Tapen Bikomi Foundation also advocates the formation of some policies to buttress the effectiveness of preventing human trafficking activities by the elements of local government in TTU Regency. These policies are intended to give the legal base of all the local government activity in preventing human trafficking based on the higher rule of law (even in province or nation) by considering the relevant condition in TTU Regency. Some policies produced, for example, the Decree of TTU Regency No.190/KEP/HK/IV/2018 concerning the Formation of the Anti-Trafficking Task Force and Prevention and Handling of Prospective Indonesian Workers/Troubled/NonProcedural Indonesian Workers of Timor Tengah Utara Regency; Regulation of Atmen Village regarding Legal Migration Procedures And Prevention Of Human Trafficking in Atmen Village; Regulation of Letmafo Village regarding Legal Migration Procedures And Prevention Of Human Trafficking in Atmen Village. In addition, at the time of this research, the Tapen Bikomi Foundation was also helped prepare the plan-making regulation of Oenenu 
Village regarding legal migration and prevention of human trafficking, and actively encouraging the formation of regency regulation in the prevention of human trafficking in TTU Regency. The Bikomi Tapen Foundation is also diligently overseeing the implementation of these regulations, and various actions or activities carried out by various government agencies in preventing human trafficking in TTU Regency.

Besides strengthening capacity, the Tapen Bikomi Foundation also provides various forms of help or assistance needed to ensure the effectiveness of human trafficking prevention measures carried out by various government institutions in the Timor Tengah Utara Regency. The provision of this help carried out through coordination between the Tapen Bikomi Foundation and various government agencies, to obtain various resources that support the success of these prevention efforts. Such assistance such as the contribution of thoughts in arranging prevention activities, support of personnel to take part in carrying out prevention activities, material support in the form of budget allocations to support prevention activities in the field, provision of training and socialization tools, provision of media to promote legal migration and human prevention trafficking (such as banners, posters, stickers), and helps build coordination with various external parties (locally within the province, nationally and across countries) in handling cases and protecting victims of human trafficking.

\section{Discussion:-}

Efforts to prevent human trafficking through community empowerment approaches through strengthening aspects of knowledge and skills are approaches used by various NGOs (Limocelli, 2016). This based on the assumption that the practice of human trafficking occurs because of weaknesses in the knowledge and skills inadequate in identifying, rejecting and preventing the practice of human trafficking. Lack of information and skills can improve one's vulnerable condition so they cannot ward off, reject, fight when faced with various modes of traffickers (Schan \& Optekamp, 2016; Riadi, 2017). So through education and training activities, it expected that the public will understand various conditions that open space for the occurrence of human trafficking practices and be able to take concrete actions to prevent the occurrence of human trafficking practices in their communities.

According to Mace, et al., The development of human resources in preventing human trafficking must begin with education and training activities for individuals and communities. Educational activities intend as the range of the first intervention to provide fundamental knowledge and understanding to develop a shared awareness about human trafficking. Training activities should build and strengthen the capabilities, facilities, and techniques for preventing human trafficking. Awareness that has been built with the knowledge of the problem of human trafficking must then be applied through certain concrete actions to prevent the practice of human trafficking (Mace, et al., 2012).

With the basic knowledge and skills on human trafficking, it hoped that community independence will emerge in carrying out various human trafficking prevention measures. Intend independence was building the power or strength of the community to face the practice of human trafficking through various concrete actions that can be done. Self-reliance is the initial capital to encourage active public participation to prevent the practice of human trafficking in the community here. Individuals and communities must direct empowerment towards independence and then the active participation of the community. In preventing human trafficking, awareness, care, independence and active participation are important elements the community must own that in a community. With empower the society through education and training, and to encourage community awareness and cooperation through the promotion of public accomplishments, the Foundation Tapen Bikomi pen can be reserved climates and driving participation in the prevention of human trafficking (Hagul, 1992).

Through community empowerment, the Bikomi Tapen Foundation provides knowledge about matters relating to human trafficking, including the model used by traffickers, the dangers of adverse effects of becoming victims of human trafficking, and legal sanctions against perpetrators. This knowledge helps the community to expect the threat of traffickers, protect themselves from various things that can cause the community to become victims of human trafficking, and to avoid themselves from various actions that lead to the practice of human trafficking. In addition, it also gives the community an understanding of legal migration procedures to prevent human trafficking. By following the legal migration procedures as determined by it, every community that wishes to become a migrant worker can avoid the opportunity to become a victim of human trafficking and guaranteed protection and fulfillment of rights as migrant workers. This knowledge is very relevant given the context in TTU Regency, where the practice of human trafficking takes place in the mode of illegal labor migration as mentioned above. By knowing the procedure, the community has the skills to prevent the practice of human trafficking and to protect themselves from the possibility of becoming victims of human trafficking. 
To ensure the effectiveness of efforts to prevent human trafficking in the TTU Regency, the Tapen Bikomi Foundation also builds cooperation with various elements of government, both local and village governments. Cooperation in the framework of preventing human trafficking is response emphasized by the United Nations, known as 4P, including prevention (related to efforts made to prevent the practice of human trafficking), protection (protection of victims of human trafficking) and persecution (application of the law to impose sanctions on the perpetrators), and partnership (cooperation between all government institutions at the international, national and local levels, non-governmental institutions and the community at large) (Barret \& Shaw, 2011).

In collaboration with various elements of the government, the Tapen Bikomi Foundation presents itself as a parallel partner with the government. Such a position enables the Tapen Bikomi Foundation to maintain the performance and dynamics of its institutions in the collaboration. That in carrying out the activities and programs of the institution, the Bikomi Tapen Foundation does not depend or become an extension of the local government. Thus, the Tapen Bikomi Foundation still has a bargaining position to decide and use resources from various sources to maintain consistency in the vision and mission and goals of the institution. Collaboration with the local government and village government can take place for the awareness of the complementary nature of the relationship to achieve a common goal, which is to prevent and combat the practice of human trafficking. Thus, it can build complementary cooperation in the pattern of partnerships between the Tapen Bikomi Foundation and government agencies.

The development of cooperation networks in partnership patterns has several benefits. First, by applying the partnership pattern, it will guarantee the accuracy in identifying and determining the target to be achieved. Second collaboration produces diverse creativity in intervening in the problems at hand. Third, the diversity of interventions will cause a quantitative and qualitative increase in problem-solving. Fourth, by applying the pattern of intimacy broader participation will be built in the form of ideas, resources and forms of problem-solving. Fifth, such synergy will produce cumulative effects that have a comprehensive impact on achieving existing targets or targets (Yunardhani, 2012).

Through cooperation in preventing human trafficking in TTU Regency between the Tapen Bikomi Foundation and local governments, both identification of the problem, setting goals and objectives and planning and implementing solutions could guarantee for accuracy. In efforts to prevent human trafficking, cooperation allows variations in strategies and steps to solve problems, so that will get closer to the goals or objectives achieved together. Collaboration between the Tapen Bikomi Foundation and the local government besides producing a variety of strategies will also impact the quality of constructive and progressive human trafficking prevention efforts. Through this collaboration, human trafficking in Central Timor Regency can become a joint development agenda so that enrichment appears in both paradigmatic and practical aspects. In addition, through the partnership pattern, efforts to prevent human trafficking are expected to touch and lead to resolving various causes. Thus, collaboration between the Tapen Bikomi Foundation with the local government and village government can produce better forms of efforts to prevent human trafficking in the TTU Regency.

To support the performance of various government agencies, the Tapen Bikomi Foundation also takes a variety of approaches. Through these approaches, the Tapen Bikomi Foundation strengthens the capacity and policy instruments of government institutions. The prevention of human trafficking is the duty and responsibility of the government to protect the entire community. The government has the authority and authority to plan, establish and take various forms of human trafficking prevention measures. Various relevant contributions must support government efforts to support the achievement of human trafficking prevention goals.

The Tapen Bikomi Foundation as an NGO in partnership with the government also contributes to supporting the tasks and roles of the government in preventing and overcoming the problem of human trafficking in Timor Tengah Utara Regency. This is done by strengthening the capacity and policies of formal institutions. The strengthening is done through efforts to improve various forms of problem interventions through sharing knowledge and skills; advocating for policymaking and changing government institutions; and provide help and support for resources needed to achieve the goals of efforts to prevent human trafficking. They need various forms of support to encourage quality practices to achieve the objectives of preventing human trafficking (Datta, et al., 2017).

In these ways, the Tapen Bikomi Foundation carries out three NGO roles, inspire, inform and improve (Pollard \& Court, 2005). The role of inspiring done by submitting views and providing help in solving problems, whether in the form of personnel, funds, and facilities. The role of information by presenting competent parties to open horizons 
and broaden government perspectives to design and implement approaches to human trafficking prevention solutions that are more comprehensive, effective. Meanwhile, the role of improving done by testing, adding, repairing and developing problem-solving activities to get the best solution to the problem, both in terms of policies and institutional practices. All forms of reinforcement carried out by the Tapen Bikomi Foundation can support government institutions to further strengthen the practice of preventing human trafficking. This can lead to the achievement of the objectives of efforts to prevent human trafficking in the Timor Tengah Utara Regency.

\section{Conclusion:-}

Prevention of human trafficking requires a comprehensive intervention involving various parties. The Tapen Bikomi Foundation as an NGO also moves to prevent human trafficking in the Timor Tengah Utara Regency, by empowering the community, building a network of cooperation and strengthening the capacity and policies of government institutions. Through these methods, the Tapen Bikomi Foundation expands the range of interventions ranging from individuals and families, norms in society, institutional practices and policy products. The expectation of this comprehensive intervention is to support the success of preventing human trafficking and saving the public from the threat of human trafficking practices in Timor Tengah Utara Regency.

\section{Bibliography:-}

1. Arif, Ghani Wal, 2016. "Peran International Organization For Migration (IOM) Dalam Mengatasi Perdagangan Manusia Di Indonesia Tahun 2010-2014”. In JOM Fisip, Vol. 3, No. 1, hal. 1-15, 2016.

2. Barrett, Nicole \& Shaw, Margaret, 2011. "Towards Human Trafficking Prevention: A Discussion Document". A Paper delivered in International and National Expert Meetings on human trafficking prevention, Montreal, Canada, 21-22 dan 23-24 Maret 2011.

3. Cohen, Larry \& Swift, Susan, 1999. "The Spectrum of Prevention: Developing a Comprehensive Approach to Injury Prevention”. In INJURY PREVENTION, Vol 5, page. 203-207, 1999.

4. Datta, Sudhanshu Shekhar \& Mukherjee, Kaushik, 2017. "Role Played by Social Workers in NonGovernmental Organization in Preventing Human Trafficking in India". In International Journal of Humanities And Social Science Invention (IJHSSI), Vol. 6, No. 12, page. 34-37, 2017

5. Hagul, Peter, 1992. Pembangunan Desa dan Lembaga Swadaya Masyarakat. Jakarta: Rajawali

6. Limoncelli, Stephanie A., 2016. "What in the World Are Anti-Trafficking NGOs Doing? Findings from a Global Study”. In JOURNAL OF HUMAN TRAFFICKING, Vol. 2, No. 4, page. 316-328, 2016.

7. Mace, Stephanie L., Venneberg, Donald L. \& Amell, James W., 2012. "Human trafficking: Integrating Human Resource Development Toward a Solution". In Developing Human Resources Journal, Vol. 14, No. 3, page. 333-344, 2012.

8. Pollard, Amy \& Court, Julius, 2005. "How Civil Society Organizations Use Evidence to Influence Policy Processes". In Babbington, Anthony \& Hickey, Samuel \& Mitlin, Diana (eds.), Can NGO’s Make A Difference? The Challenge Of Development Alternatives. Londres: ZED BOOKS.

9. Riadi, Wahyu, 2017. "Implementasi Pencegahan Tindak Pidana Perdagangan Orang Ditinjau Dari Perspektif Pertahanan Negara”. In JURNAL PRODI STRATEGI PERANG SEMESTA, Vol. 3. No. 2, hal. 1-24, 2017

10. Schans, D. \& Optekamp, C., 2016. "Raising Awareness, Changing Behavior?: Combating Irregular Migration Through Information Campaigns". in https://www.wodc.nl/ [31/08/2018].

11. Soepadmo, Dr. H. Nurianto Rachmad, S.H., M.H., M.M., 2013. Ekstradisi Pelaku Tindak Pidana Perdagangan Orang. Without publication.

12. Suparmin, Dr., SH., M.Hum AKBP (Pur), 2013. "Implementasi Pencegahan Tindak Pidana Perdagangan Orang". A paper delivered in National Converence held by PJTKI Central Java, in theme "Perlindungan Terhadap CTKI ke Luar Negeri, Mencegah Perdagangan Orang ke Luar Negeri, Pembinaan PPTKIS Kantor Cabang Jawa Tengah" in Citra Dewi Bandungan Hotel, Semarang, 5 September 2013.

13. Widiastuti, Try Wahyu, SH. MH., 2010. "Upaya Pencegahan Tindak Pidana Perdagangan Orang (Trafficking)". In WACANA HUKUM, Vol. IX, hal. 107-120, 2010.

14. Yunardhani, Rakei, 2012. Kondisi Pencegahan Kejahatan Berbasis Masyarakat (Community Crime Prevention) Di Wilayah Perbatasan Indonesia-Malaysia (Pulau Nunukan dan Pulau Sebatik Provinsi Kalimantan Timur). A Tesis in Crimonology Departement, Indonesia University, Jakarta. 